This is an electronic reprint of the original article. This reprint may differ from the original in pagination and typographic detail.

Author(s): Hepola, Janne; Karjaluoto, Heikki; Hintikka, Anni

Title: $\quad$ The effect of sensory brand experience and involvement on brand equity directly and indirectly through consumer brand engagement

Year: $\quad 2017$

Version:

Please cite the original version:

Hepola, J., Karjaluoto, H., \& Hintikka, A. (2017). The effect of sensory brand experience and involvement on brand equity directly and indirectly through consumer brand engagement. Journal of Product and Brand Management, 26(3), 282-293. https://doi.org/10.1108/JPBM-10-2016-1348

All material supplied via JYX is protected by copyright and other intellectual property rights, and duplication or sale of all or part of any of the repository collections is not permitted, except that material may be duplicated by you for your research use or educational purposes in electronic or print form. You must obtain permission for any other use. Electronic or print copies may not be offered, whether for sale or otherwise to anyone who is not an authorised user. 


\title{
The effect of sensory brand experience and involvement on brand equity directly and indirectly through consumer brand engagement
}

\begin{abstract}
Purpose - This study examines the effect of sensory brand experience and involvement on brand equity directly and indirectly through cognitive, emotional and behavioral consumer brand engagement.

Design/methodology/approach - A survey was administered to the customers of a Finnish tableware brand using relevant Facebook channels. A total of 1385 responses were analyzed using partial least squares structural equation modeling.

Findings - The empirical findings suggest that both involvement and sensory brand experience are directly related to the three facets of consumer brand engagement. Further, involvement, sensory brand experience and consumer brand engagement jointly explain more than $50 \%$ of the variance in brand equity. In addition, the results reveal that emotional engagement was the most influential factor in determining consumers' overall engagement level.
\end{abstract}

Research limitations/implications - The framework should be tested in other contexts and the application of longitudinal research setting is encouraged.

Practical implications - The study highlights not only the importance of holistic consumer brand engagement management but also the necessity to manage sensory aspects of consumer-brand interactions. In this way, managers can build sustainable consumer-brand relationships.

Originality/value - The nomological network of consumer brand engagement is not wellknown. This study integrates two central constructs (sensory brand experience and brand 
equity) with the concept of consumer brand engagement and examines their effects on brand equity both directly and indirectly through cognitive, emotional and behavioral consumer brand engagement.

Keywords Consumer brand engagement, Brand equity, Sensory brand experience, Formative measurement, Brand relationship

\section{Introduction}

In the marketing literature, the attention paid to consumer brand engagement $(\mathrm{CBE})$ has been rapidly increasing (e.g., Brodie et al., 2011; Hollebeek et al., 2016; Pansari and Kumar, 2016). In fact, the Marketing Science Institute (MSI) has identified consumer engagement as a key research priority (MSI, 2014). In general, the concept is viewed as a strategic imperative that directly influences firm performance (Kumar and Pansari, 2016; Pansari and Kumar, 2016). Further, Dwivedi (2015) found that the substantial influence of CBE on consumer loyalty goes beyond the effects of perceived quality, value and satisfaction. Thus, in addition to being interesting from the theoretical perspective, it is evident that the concept also has important managerial implications.

Although there are various conceptualizations of engagement (e.g., Bowden, 2009; Calder et al., 2009; Sprott et al., 2009; van Doorn et al., 2010; Kumar and Pansari, 2016), many studies view engagement as a multi-dimensional phenomenon that consists of cognitive, emotional and behavioral dimensions (e.g., Brodie et al., 2011; Hollebeek et al., 2014; Dwivedi, 2015). In particular, Hollebeek et al. (2014, p. 149) define CBE as “a consumer's positively valenced brand-related cognitive, emotional and behavioral activity during or related to focal consumer/brand interactions". Unfortunately for marketing managers, the field remains in its infancy; despite recent efforts to extend the nomological network of cognitive, emotional and 
behavioral CBE (e.g., Hollebeek et al., 2014; Leckie et al., 2016), there is still much to be known about their antecedents and outcomes (Brodie et al., 2011).

The state of affairs suggests a fruitful means to extend our knowledge in theoretical terms and to acquire important managerial insight by examining the nomological network of cognitive, emotional and behavioral CBE. Similarly to engagement, researchers have strongly started to emphasize the vital role of experiences in marketing (e.g., Brakus et al., 2009; Lemon and Verhoef, 2016; Verhoef et al., 2009). Still, the concepts of brand experience and brand engagement remain largely unconnected. In general, brand experience is defined as "sensations, feelings, cognitions, and behavioral responses evoked by brand-related stimuli that are part of a brand's design and identity, packaging, communications, and environments" (Brakus et al., 2009, pp. 52). One central difference between these two concepts seems to be that experiences do not presume a motivational state (Brakus et al., 2009), whereas CBE is a motivational construct (Hollebeek, 2011b; Hollebeek et al., 2014). However, distinguishing them is difficult in practice because they both have cognitive, affective and behavioral dimensions and the measurement items are almost identical (see Brakus et al., 2009; Hollebeek et al., 2014). This suggests that there is likely an overlap between these two constructs. For this reason, focusing on sensory brand experience, a dimension not associated with CBE (Brodie et al., 2011; Hollebeek, 2011a; Hollebeek et al., 2014), seems reasonable. From managerial perspective, this is relevant because it is known that multi-sensory brand experiences can be used to build customer equity (Hultén, 2011), that is, the value of customer to a specific company (Leone et al., 2006).

Both academics and practitioners should also be interested in consequences of CBE beyond brand usage intent (Hollebeek et al., 2014) and brand loyalty (Leckie et al., 2016). In particular, brand equity (e.g., Leone et al., 2006; Yoo et al., 2000; Keller, 1993) is considered 
as a vital element of market success and is thus of high relevance to brand managers. For instance, given that brand equity concerns a different consumer response to branded than to unbranded products (e.g., Keller, 1993; Yoo and Donthu, 2001; Ailawadi et al., 2003), brand equity can be viewed as one of the most valuable brand-related assets (Keller, 1993). By examining brand equity as a consequence of $\mathrm{CBE}$, both managers and academics are better able to evaluate the importance of CBE.

The paper is arranged as follows: first, the theoretical framework and the related hypotheses are presented. Then, we describe our research methods after which we present the empirical results. The final section discusses the implications for academics and practitioners, the study's limitations and directions for future research.

\section{Theoretical background}

The theoretical discussion is based on three broader conceptual streams: the service-dominant logic, consumer culture theory and relationship marketing (cf. Hollebeek et al., 2014). The service dominant logic views consumers as active co-creators of value (Vargo and Lusch, 2004, 2008) and consumer culture theory emphasizes the experiential aspects of consumption (Arnould and Thompson, 2005). In addition, relationship marketing with customer engagement incorporated views experiences as a mean for relationship management (Vivek et al., 2012). These conceptual underpinnings help to understand the proposed research model in greater depth.

The investigated research model includes six measured variables in total (Figure 1). We examine the effect of personal involvement on CBE dimensions, namely cognitive processing (H1a), affection (H1b) and activation (H1c), and on brand equity (H2). Similarly, we investigate the influence of sensory brand experience on cognitive processing $(\mathrm{H} 3 \mathrm{a})$, affection (H3b), activation (H3c) and brand equity (H4). Weights (w1, w2 and $w 3)$ represent 
the importance of CBE dimensions in formation of the CBE construct. Finally, we examine the impact of formatively measured CBE on brand equity (H5).

\section{---- INSERT FIGURE 1 ABOUT HERE ----}

\section{Nature of consumer brand engagement}

$\mathrm{CBE}$ is based on interactions and the subsequent interactive experiences between the engagement subject and the engagement object (e.g., Hollebeek, 2011a, 2011b; Dwivedi, 2015). Generally, the marketing literature focuses on the consumer (e.g., Hollebeek et al., 2014; Dwivedi, 2015) or the customer (e.g., Brodie et al., 2011; Vivek et al., 2012; De Vries and Carlson, 2014) as the subject of engagement. However, engagement objects may vary. In particular, consumer engagement has been studied in the context of brands (e.g., Hollebeek et al., 2014; Dwivedi, 2015), whereby the term "consumer brand engagement" has been adopted.

As previously mentioned, recent studies (e.g., Hollebeek et al., 2014; Hollebeek and Chen, 2014; Dwivedi, 2015) emphasize the multidimensional nature of CBE. Although different dimensions have been proposed to capture the holistic nature of the concept (e.g., Hollebeek et al., 2016; Vivek et al., 2014), CBE is generally believed to consist of cognitive, emotional and behavioral dimensions (e.g., Hollebeek et al., 2014; Hollebeek and Chen, 2014; Dwivedi, 2015). The relative importance of these engagement dimensions may vary according to context (Brodie et al., 2011). Hollebeek et al. (2014) characterized CBE as the total cognitive, emotional and behavioral activity during/related to the interaction with engagement object and constructed a measurement scale for CBE. This type of activity/investment focus on interactions is adopted by many other studies (e.g., Hollebeek, 2011a, b; Hollebeek et al., 2016). Hollebeek et al. (2014, p. 154) referred to these dimensions as cognitive processing, affection and activation: 
Cognitive processing: "a consumer's level of brand-related thought processing and elaboration in a particular consumer/brand interaction".

Affection: "a consumer's degree of positive brand-related affect in a particular consumer/brand interaction".

Activation: "a consumer's level of energy, effort and time spent on a brand in a particular consumer/brand interaction".

Similar dimensions can be identified in the literature. For example, immersion (e.g., Hollebeek, 2011b; Hollebeek and Chen, 2014), absorption (e.g., Dessart et al., 2015; Dwivedi, 2015; Hollebeek, 2011a) and attention (e.g., Dessart et al., 2015, 2016) are similar to cognitive processing. Passion (e.g., Hollebeek, 2011b; Hollebeek and Chen, 2014; Merrilees, 2016) and dedication (e.g., Dwivedi, 2015) are unlikely to differ significantly from affection. Finally, activation (e.g., Hollebeek et al., 2014; Hollebeek, 2011b) resembles vigor (e.g., Dwivedi, 2015).

As an emerging concept, consumer engagement has been conceived of in several other ways (Table I). For example, a number of scholars (e.g., Sprott et al., 2009; Goldsmith et al., 2011, 2014) focus on the propensity of consumers to include brands in their self-concepts (brand engagement in self-concept). However, this approach limits the interactive nature of engagement (Hollebeek et al., 2014). Calder et al. (2009) view engagement as an overall set of experiences (see also Vernuccio et al., 2015). However, they conducted their study in the context of websites, not in the brand context. In addition, experience and engagement can be considered to represent different entities (Hollebeek et al., 2014; Brakus et al., 2009). We consider the approach represented, for instance, by Hollebeek and Brodie the most developed and thus adopt their concept of CBE. 


\section{---- INSERT TABLE I ABOUT HERE ----}

\section{Nature of brand equity}

Brand equity can be viewed as the added value that is linked to a specific product by the consumer's thoughts, words and actions (Leone et al., 2006). Keller (1993) stated that customer-based brand equity is associated with situations in which customers hold favorable, strong and unique brand associations in memory. Thus, products with high levels of brand equity would be considerably less valuable without the brand name. Many researchers (e.g., Ailawadi et al., 2003; Keller, 1993) define brand equity as the difference in effects between a branded and an unbranded product. In particular, Yoo and Donthu (2001, p. 1) define brand equity as the "consumers' different response between a focal brand and an unbranded product when both have the same level of marketing stimuli and product attributes". Although brand equity (referred to as overall brand equity by Yoo and Donthu, 2001) can be operationalized as a tendency to choose branded product over similar unbranded product, customer-based brand equity consists of four components: loyalty, brand awareness, perceived quality and brand associations (Yoo and Donthu, 2001).

\section{Role of personal involvement}

Involvement has received attention as a required antecedent of CBE (e.g., Dwivedi, 2015; France et al., 2016; Hollebeek, 2011a; Hollebeek et al., 2014). Three types of involvement can be identified: (1) situational involvement is evoked in a particular situation; (2) enduring involvement relates to inherent and ongoing concern with an object; (3) response involvement refers to the extent of the decision-making process (Bloch and Richins, 1983; Zaichkowsky, 1985; Houston and Rothschild, 1978). However, the general view of involvement emphasizes the relevance or the importance of the object (e.g., Greenwald and Leavitt, 1984; Petty et al., 
1983; Zaichkowsky, 1985, 1994). For example, Zaichkowsky (1985) defines involvement as “a person's perceived relevance of the object based on inherent needs, values, and interest".

The level of consumer motivation increases as a function of felt involvement (Bloch et al., 1986; Zaichkowsky, 1984, 1994). If the object (e.g., brand) is relevant to the consumer, he or she is likely to exert greater cognitive efforts in analyzing the object-related situations and thus analyze them in greater detail (Greenwald and Leavitt, 1984; Celsi and Olson, 1988). Because consumer attention is focused on object-related information, the number of objectrelated thoughts and inferences relative to the number of overall thoughts is larger (Celsi and Olson, 1988). This phenomenon reflects a deeper level of object-related cognitive elaboration (Hollebeek et al., 2014). Therefore, we propose the following hypothesis:

H1a. Personal involvement is positively related to cognitive processing.

Emotions arise from the cognitive appraisal of events or one's own thoughts (e.g., Roseman, 1991; Smith and Ellsworth, 1985; Bagozzi et al., 1999). Thus, positive emotions are responses to the favorable outcomes that consumers are motivated to achieve (Roseman, 1991; Bagozzi et al., 1999; Johnson and Stewart, 2005), such as experiencing fun and pleasure, in addition to task-related objectives in the case of highly involved consumers (Mathwick and Rigdon, 2004; Bloch et al., 1986). Consequently, a situation must be relevant to the consumer so that an emotional response may occur (Bagozzi et al., 1999). If the outcome of an event is congruent with the consumer's desires or needs, the arising positive emotions are stronger for consumers with high personal involvement (Nyer, 1997). Therefore, we propose the following hypothesis:

H1b. Personal involvement is positively related to affection. 
Highly involved consumers are motivated towards the object (e.g., Zaichkowsky, 1985, 1994), and the level of an individual's motivation is vital in determining the level of activation (Kroeber-Riel, 1979). For instance, Mittal and Lee (1989) relate product involvement to the interest in possessing the specific product. Thus, because consumers are involved with a specific object (e.g., brand), they are willing to invest more effort in it. For example, Clarke and Belk (1978) found that more stores were visited by shoppers searching for high-involvement products than for low-involvement products. In addition, Celsi and Olson (1988) found that the higher the felt involvement with product information was, the more time consumers spent attending to the product information. Thus, we propose the following hypothesis:

H1c. Personal involvement is positively related to activation.

Given that highly involved consumers are motivated towards the object due to the increased importance or relevance (Zaichkowsky, 1985, 1994), personal involvement should also be reflected in increased levels of brand equity. Compared with CBE, involvement is not based on an interactive relationship with the object (Brodie et al., 2011). Thus, involvement represents a more passive phenomenon. However, involved consumers should respond differently to similar branded and unbranded products, which is commonly used as a sign of brand equity (e.g., Yoo and Donthu, 2001). Quester and Lim (2003) found that interest and pleasure, two subcomponents of product involvement that were merged into one factor, had a positive effect on brand loyalty. This outcome is particularly interesting for this study because brand loyalty can be considered one of the components of brand equity (Aaker, 1991). However, such effects might be mediated through other constructs. For instance, Hollebeek et al. (2014) found that CBE fully mediates the effect of personal involvement on purchase intention. Nevertheless, we state the following hypothesis: 
H2. Personal involvement is positively related to brand equity.

\section{Role of sensory brand experience}

Brakus et al. (2009) divided brand experience into four dimensions: intellectual, affective, behavioral and sensory experience. Given that consumers always use their senses to perceive products (Hekkert and Schifferstein, 2008), the sensory dimension can be viewed as a central dimension of brand experience. Sensory brand experience can be defined as "sensations [...] evoked by brand-related stimuli that are part of a brand's design and identity, packaging, communications, and environments" (Brakus et al., 2009, p. 52). These sensations may be related to any of the five senses: smell, sound, sight, taste and touch (Hultén, 2011; Fenko et $a l ., 2010)$. The different senses specialize in different types of information (Schifferstein, 2010). However, the literature (e.g., Bahrick and Lickliter, 2000; Ernst and Bülthoff, 2004) suggests that the larger the number of senses that are stimulated, the stronger and richer the experiences or other outcomes are. However, the importance of different senses may vary during different periods of product use. During the purchase event, vision is the dominant sensory modality, whereas touch and audition become more important during later stages (Fenko et al., 2010).

Object-related (e.g., brand) sensory information can capture the individual's attention and block other stimuli from entering the individual's mind (Biocca and Delaney, 1995; Spangenberg et al., 1996), which supports object-related thought processing and elaboration. The breadth and depth of the sensory information affect the individual's plunging into something, which results in immersion (Shih, 1998; Carù and Cova, 2006). Therefore, consumers may perceive that time passes faster if they are, for instance, in a scented environment (Spangenberg et al., 1996) or hear a certain type of music (Kellaris and Altsech, 1992). In addition, these types of sensory expression can be a source of inspiration (Hultén, 
2011) and thus increasing the level of brand-related cognitive processing. Based on these findings, we propose the following hypothesis:

H3a. Sensory brand experience is positively related to cognitive processing.

Sensory stimulation may provide aesthetic pleasure and excitement (Schmitt, 1999), and thus can be used to affect consumer emotional states (Hultén, 2011). Holbrook and Hirschman (1982) suggested that consumption partly relies on consumer fantasies, feelings and fun and that multisensory aspects should be used to understand enjoyment. In fact, Baumgartner et al. (2006) found that congruent visual and musical emotional stimuli automatically evoke strong emotional feelings and experiences. Beckman et al. (2013) found that sensory experience was a strong predictor of an individual's place dependence, which provides emotional benefits to the individual. In addition, scents and music, for instance, may affect consumer affects (Ellen and Bone, 1998; Bruner, 1990). Therefore, we propose the following hypothesis:

H3b. Sensory brand experience is positively related to affection.

If consumers experience sensations, it is likely that they are willing to receive such stimulation again (Brakus et al., 2009). Therefore, consumers are encouraged to invest their behavioral inputs in the specific relationship. For instance, Milliman $(1982,1986)$ found that music tempo variations may affect behavioral responses, such as the length of stay and the amount of purchases. Similarly, Spangenberg et al. (1996) found that the presence of ambient scent may increase various approach behaviors. In addition, Barnes et al. (2014) studied sensory brand experience in the tourism context and found that sensory brand experience had a positive impact on revisit intention. Accordingly, we propose the following hypothesis:

H3c. Sensory brand experience is positively related to activation. 
Generally, brand experience has been empirically linked to brand loyalty (e.g., Brakus et al., 2009), a subcomponent of brand equity (Aaker, 1991). The holistic nature of experiences makes it difficult for competitors to mimic them (Berry et al., 2002; Gentile et al., 2007), particularly in terms of sensory experiences that relate to five senses. Consequently, sensory brand experiences can form brand associations (Keller, 1993), which is a subcomponent of brand equity (Aaker, 1991). These sensory experiences help differentiate the brand in the minds of consumers (Hultén, 2011). In addition, consumers must re-interact with the same brand if they want to re-experience these experiences, which creates a motivational force towards the brand. Therefore, we propose the following hypothesis:

H4. Sensory brand experience is positively related to brand equity.

\section{Consumer brand engagement and brand equity}

Generally, loyalty and purchase intention are identified as consequences of CBE (e.g., Dwivedi, 2015; Hollebeek et al., 2014). Highly engaged consumers are holistically invested in the brand interactions (Hollebeek, 2011b; Hollebeek and Chen, 2014) and thus develop a deep bond with the brand (Dwivedi, 2015). Consequently, they are likely to have unique brand associations (Aaker, 1991; Keller, 1993). Consumers also tend to maintain these types of rewarding relationship (Homans, 1958). In addition, the benefits that CBE provides are linked to a specific brand (e.g., Brodie et al., 2011; Dwivedi, 2015), which should inevitably increase brand equity. Therefore, we propose the following hypothesis:

H5. Consumer brand engagement is positively related to brand equity.

\section{Methods}

\section{Data collection}


The data were collected through an online survey targeted at customers of a Finnish tableware brand. Data collection platforms included the Facebook page of the brand and other Facebook groups in which the brand's customers participate. The data were gathered during summer 2015. The survey items were translated by a native Finnish speaking researcher and back-translated by another Finnish speaking researcher.

In total, 1,385 responses were received ( 5 responses were eliminated because the respondents were younger than 18 years). The great majority of the respondents were female $(95.3 \%)$. We later established partial measurement invariance (Henseler et al., 2016; $p>0.05$ ) and conducted group comparison using PLS-MGA (Henseler et al., 2009). We found that the structural estimates do not differ between female and male $(p>0.05)$, meaning that the large proportion of women does not bias the results. The age groups represented in the sample varied as follows. A total of $12.7 \%$ were between 18 and 25 years. A total of $24.7 \%$ were between 26 and 35 years. A total of $21.4 \%$ were between 36 and 45 years. A total of $23.3 \%$ were between 46 and 55 years, and $17.8 \%$ were 56 years or older. Further, the relationship duration with the brand varied as follows: less than 6 months $(2.1 \%)$, between 6 months and 4 years $(9.9 \%)$, between 5 and 20 years $(47.1 \%)$ and over 20 years $(40.9 \%)$. To evaluate nonresponse bias, a comparison of early $(\mathrm{N}=400)$ and late respondents $(\mathrm{N}=400)$ was conducted. The Mann-Whitney U test did not reveal any statistically significant differences between the two groups at $p<0.05$, which suggests that nonresponse bias is not an issue.

\section{Measurement}

The measures (Appendix) were based on the following studies: personal involvement (Zaichkowsky, 1994; 10 items), sensory brand experience (Brakus et al., 2009; 3 items), CBE dimensions (Hollebeek et al., 2014; 10 items) and brand equity (Yoo and Donthu, 2001; 4 items). The selection of appropriate measurement model (reflective or formative) is critical 
because misspecification may severely bias the structural estimates (Jarvis et al., 2003). The application of the reflective measurement model in the context of engagement seems to be widespread (e.g., Calder et al., 2009; Dwivedi, 2015). Given the strong focus on the dimensional nature of engagement (e.g., Hollebeek et al., 2014; Brodie et al., 2011), we find it uncomfortable to apply such reflective models (see selection criteria from Jarvis et al., 2003) in this context and instead apply the formative measurement model.

Empirical support for the formative measurement model was examined using confirmatory tetrad analysis (PLS-CTA) (see Gudergan et al., 2008). We obtained the composite scores for different dimensions and used them as manifest variables. Because CBE had only three indicators, we followed the advice of Gudergan et al. (2008) and added one unrelated indicator. An indicator from the dependent variable with the highest cross loading (0.628) was selected. As in all evaluations of statistical significance in this study, the statistical significance of the results was tested using a bootstrapping procedure (Henseler et al., 2009) with 5,000 sub-samples. The Bonferroni-adjusted $95 \%$ bias-corrected bootstrap (two-tailed) confidence interval limits do not include zero ([0.232; 0.489]; [0.193; 0.439]) and thus support the second-order formative measurement.

\section{Assessment of common method variance}

Because of the applied data-gathering method, common method variance may influence the structural estimates of the model (Podsakoff et al., 2003). To mitigate the effect of common method variance, the respondents were allowed to answer anonymously, the questionnaire was kept short (44 items) and the items were formulated as unambiguously as possible. We used Harman's (1976) single-factor test to assess the effect of common method variance on the study results. The single factor, extracted using principal axis factoring with no rotation, explained only $41.7 \%$ of the overall variance. Given that the one-factor solution does not 
account for the majority of the variance, common method variance is unlikely to bias the path model results (Podsakoff et al., 2003). Further, following Podsakoff et al. (2003), a PLS model with a common method factor with indicators that included all the principal constructs was run, and each indicator's variance was substantively explained by the principal construct. This analysis shows that average variance substantively explained the variance of the indicators $(0.720)$, while the average method-based variance was 0.005 . Therefore, common method variance is unlikely to be a serious concern in this study.

\section{Results}

The structural model (Figure 1) was estimated using partial least squares structural equation modeling with SmartPLS 3.2 (Ringle et al., 2015). We find this approach particularly applicable because of the theory-developing nature of this research and the necessity of applying a formative measurement model (Hair et al., 2011).

\section{Assessment of reflective measurement models}

One indicator was removed due to low loading $(<0.4)$. The remaining loadings were high and significant $(p<0.01)$. Only the loading of the seventh indicator of personal involvement (0.693) was lower than 0.7. In addition, the composite reliabilities and average variance extracted (AVE) values were over the suggested levels of 0.7 and 0.5 , respectively (Hair $e t$ $a l .$, 2011) (Appendix). Thus, convergent validity was established.

Discriminant validity was first evaluated through indicator cross loadings, which revealed that no indicator loaded higher on any opposing construct. Second, we applied Fornell and Larcker's (1981) criterion: the square root of AVE for each reflective construct was larger than the correlation between the latent variable and all other reflectively measured constructs (Table II). However, the correlation between affection and the formatively measured engagement construct exceeded the square root of AVE. This outcome was not unexpected 
and not critical in higher-order formative models (Hair et al., 2013). Therefore, discriminant validity was established.

\section{---- INSERT TABLE II ABOUT HERE----}

\section{Assessment of formative measurement model}

Excessive collinearity between indicators is problematic in formative measurement models because it makes it difficult to separate the distinct effect of a particular indicator on a dependent variable (Diamantopoulos and Winklhofer, 2001). The VIF values for the different dimensions of CBE ranged from 1.393 to 2.214 . They were substantially below the critical level of 10 (Henseler et al., 2009), which suggests that multicollinearity is not a severe issue in this study. In addition, the weights of cognitive processing $\left(w_{1}=0.150\right)$, affection $\left(w_{2}=\right.$ $0.592)$ and activation $\left(w_{3}=0.431\right)$ were all significant $(p<0.01)$. Thus, we can proceed with the proposed formative measurement model.

\section{Assessment of structural model}

Because the model includes dependent formative constructs, we adopted the repeat indicator approach with mode B and the path-weighting scheme, as suggested by Becker et al. (2012). The analysis of the structural relations reveals that personal involvement was directly associated with all dimensions of CBE, which supports H1a-c (Table III). Personal involvement was also positively related to brand equity, which supports H2. Similarly, sensory brand experience exhibited a positive impact on all CBE dimensions, which supports H3a-c. However, the total variance explained $\left(R^{2}\right)$ was surprisingly low in activation. In addition, sensory brand experience positively influenced brand equity, which supports H4. Finally, CBE was connected with brand equity, which supports H5. In addition, when each CBE dimension was directly connected with brand equity, rather than via the formatively measured CBE construct, affection $(\beta=0.237)$ and activation $(\beta=0.272)$ exhibited a positive 
impact ( $p<0.01)$, whereas cognitive processing $(\beta=0.015)$ had no effect. In this model, the effects of personal involvement $(\beta=0.112)$ and sensory brand experience $(\beta=0.276)$ on brand equity were also both significant $(p<0.01)$.

\section{---- INSERT TABLE III AROUND HERE ----}

We also assessed the indirect and mediation effects. The mediation analysis was conducted through assessing the significance of the indirect effect via the mediator using the bootstrapping procedure, as suggested, for example, by Preacher and Hayes (2008) and Zhao et al. (2010). The indirect effect of personal involvement on brand equity via CBE was 0.155 $(p<0.01)$ (a total effect of $0.246, p<0.01)$. The VAF value of 0.630 indicates partial mediation (Hair et al., 2013). Similarly, sensory brand experience exhibited an indirect effect of $0.184(p<0.01)$ (a total effect of $0.436, p<0.01$ ). The VAF value of 0.422 indicates partial mediation (Hair et al., 2013).

\section{Discussion}

This study extends the nomological network of CBE by integrating two constructs into it: sensory brand experience and brand equity. Sensory brand experience exhibited a positive impact on the cognitive (cognitive processing), emotional (affection) and behavioral (activation) dimensions of CBE. This topic is particularly intriguing because the relationship between experience and engagement is controversial (Hollebeek et al., 2014; Calder et al., 2009). However, the joint capability with personal involvement to explain variance in activation was weak. Given the strong focus on experiences in the modern marketing (e.g., Pine and Gilmore, 1998; Brakus et al., 2009), this can be considered surprising. However, other types of experiences might be more capable of predicting consumer behavior (see Brakus et al., 2009; Calder et al., 2009). Therefore, other drivers of activation should be considered. Sensory brand experience also directly influenced brand equity. Consequently, 
these findings strengthen our understanding of sensory approaches as a vital tool in brand management (e.g., Hultén, 2011; Lindstrom, 2005; Beckman, 2013).

This study also empirically identified brand equity as an outcome of CBE. In particular, this is intriguing because brand equity can be viewed as one of the most valuable brand-related assets (Keller, 1993). Consequently, the results support the pivotal role of CBE in modern marketing. Previous studies suggest that CBE exhibits a positive effect on brand usage intent (Hollebeek et al., 2014) and brand loyalty (Leckie et al., 2016). Therefore, our study provides more insight regarding the types of outcomes CBE has an effect on. In addition, we found that affection was the most important dimension in determining the overall engagement level, which highlights the central role of emotions in this context. However, when the effects of different $\mathrm{CBE}$ dimensions on brand equity were directly modeled rather than through the formative engagement construct, the effect of cognitive processing was not significant. This result resembles that of Hollebeek et al. (2014) in terms of the insignificant impact of cognitive processing on brand usage intention in the social media setting (see also Leckie $e t$ $a l ., 2016)$. Naturally, this outcome raises the question of the scale's functionality; one reason for the result might be that cognitive processing was relatively highly correlated with affection. Researchers might wish to reassess the scale and compare alternative scales (e.g., Dwivedi, 2015; Vivek et al., 2014). Alternatively, cognitive processing simply does not influence these types of outcomes.

The study also offers several other theoretical contributions. We found that personal involvement had an indirect impact on brand equity via CBE. However, it also directly influenced brand equity (partial mediation). In their study, Hollebeek et al. (2014) found complete mediation in terms of the relationship between personal involvement, $\mathrm{CBE}$ and brand usage intention. Given that brand equity consists of loyalty, brand awareness, perceived quality and brand associations (Yoo and Donthu, 2001), personal involvement has 
likely influenced other components than loyalty in this case. For instance, the emotional nature of involvement (Zaichkowsky, 1994) may bias consumer's quality evaluations (Bagozzi et al., 1999). It is also possible that affection insufficiently captures more intense emotions, such as passion (e.g., Hollebeek, 2011b; Hollebeek and Chen, 2014), leading to a spurious significant direct effect of involvement in the tableware context (Hollebeek et al., 2014 examined social media platforms). We also demonstrate that considering the definition and operationalization of CBE provided by Hollebeek et al. (2014) researchers should apply formative measurement instead of the commonly used reflective measurement if they wish to construct a higher-order model. Given that misspecification may severely bias the structural estimates (Jarvis et al., 2003), this finding is particularly important and provides guidelines for future studies.

\section{Managerial implications}

This study has important implications for brand managers who aim to holistically engage consumers and build brand equity. Brand equity is essential in building the long-term success of firms (Leone et al., 2006). Given the connection between CBE and brand equity, managers should focus on tactics and strategies that engage consumers. In particular, increasing the consumer's emotional activity and activation during the consumer/brand interaction are the two most important dimensions when the overall engagement levels are assessed.

Consequently, managers should pay attention to both experiential and behavioral aspects of $\mathrm{CBE}$. The results also suggest that sensory brand experience provides managers a way to build brand equity. Thus, brand managers should consider how they can harness five human senses to effectively co-create powerful sensations with their customers. Finally, managers may want to consider leveraging consumer's involvement with the brand although its direct impact is relatively small. 
The dimensions of CBE (i.e., cognitive processing, affection and activation) can be affected by enhancing the level of personal involvement and co-creating sensory brand experiences. In particular, strengthening personal involvement and sensory brand experience is an effective way to enhance the level of emotional engagement. However, managers need to consider other means to influence the level of activation because the two constructs did not have a particularly strong impact on activation; managers should evaluate the relevance of other types of experiences, such as affective experience, in driving behavioral engagement.

\section{Limitations and future research}

This study has some limitations. First, the study was conducted in the context of a single Finnish tableware brand. Thus, the results may vary in different contexts, such as in other industries and cultures. Second, brand equity was considered as an outcome of CBE. However, engagement is a process (e.g., Brodie et al., 2011). Given that increased brand equity is also valuable to the customer (Aaker, 1991; Yoo et al., 2000), future studies may highlight its role as an antecedent of engagement. Thus, to achieve a better understanding of the role of $\mathrm{CBE}$, longitudinal studies would be important. Given that brand equity can be divided into different components (Yoo and Donthu, 2001), researchers might want to examine the different impact of consumer engagement on these components to derive additional insight. In addition, three-dimensional engagement studies are primarily qualitative, which calls for quantitative perspective to the CBE studies. Generally, understanding the different roles of engagement dimensions in various contexts requires additional quantitative studies.

In a more general level, researchers are encouraged to examine experience-engagement dichotomy to a greater extent in the future. Although there are some minor conceptual differences proposed between the two concepts (Hollebeek et al., 2014), the measurement 
scales for respective dimensions of experience (e.g., Brakus et al., 2009) and engagement (e.g., Hollebeek et al., 2014) are very similar in practice. For this reason, academics should be very accurate when defining these two concepts and creating measurement items for them. Researchers might also wish to evaluate different CBE measurement scales (e.g., Dessart et al., 2016; Dwivedi, 2015; Vivek et al., 2014) so that it could be better understood, how well, if at all, different consumer engagement studies can be compared. 


\section{References}

Aaker, D.A. (1991), Managing Brand Equity, Free Press, New York.

Ailawadi, K.L., Lehmann, D.R. and Neslin, S.A. (2003), "Revenue Premium as an Outcome Measure of Brand Equity", Journal of Marketing, Vol. 67 No. 5, pp.1-17.

Arnould, E. and Thompson, C.J. (2005), "Consumer Culture Theory: Twenty Years of Research", Journal of Consumer Research, Vol. 31 No. 4, pp. 868-882.

Bagozzi, R.P., Gopinath, M. and Nyer, P.U. (1999), "The Role of Emotions in Marketing”, Journal of the Academy of Marketing Science, Vol. 27 No. 2, pp. 184-206.

Bahrick, L.E. and Lickliter, R. (2000), “Intersensory redundancy guides attentional selectivity and perceptual learning in infancy", Developmental Psychology, Vol. 36 No. 2, pp. 190-201.

Barnes, S.J., Mattsson, J. and Sørensen, F. (2014), "Destination brand experience and visitor behavior: Testing a scale in the tourism context", Annals of Tourism Research, Vol. 48 (September), pp. 121-139.

Baumgartner, T., Lutz, K., Schmidt, C.F. and Jäncke, L. (2006), “The emotional power of music: How music enhances the feeling of affective pictures", Brain Research, Vol. 1075 No. 1, pp. 151-164.

Becker, J.M., Klein, K. and Wetzels, M. (2012), "Hierarchical Latent Variable Models in PLS-SEM: Guidelines for Using Reflective-Formative Type Models”, Long Range Planning, Vol. 45 No. 5-6, pp. 359-394.

Beckman, E., Kumar, A., and Kim, Y.K. (2013), "The Impact of Brand Experience on Downtown Success", Journal of Travel Research", Vol. 52 No. 5, pp. 646-658.

Berry, L.L., Carbone, L.P. and Haeckel, S.H. (2002), "Managing the Total Customer Experience”, MIT Sloan Management Review, Vol. 43 No. 3, pp. 85-89.

Biocca, F. and Delaney, B. (1995), "Immersive virtual reality technology", in Biocca F. and Levy, M.R. (Eds.), Communication in the Age of Virtual Reality, Lawrence Erlbaum Associates, Hillsdale, pp. 57-124.

Bloch, P.H. and Richins, M.L. (1983), "A Theoretical Model for the Study of Product Importance Perceptions”, Journal of Marketing, Vol. 47 No. 3, pp. 69-81.

Bloch, P.H., Sherrell, D.L. and Ridgway, N.M. (1986), "Consumer Search: An Extended Framework", Journal of Consumer Research, Vol. 13 No. 1, pp. 119-126.

Bowden, J.L-H. (2009), “The Process of Customer Engagement: A Conceptual Framework”, Journal of Marketing Theory and Practice, Vol. 17 No. 1, pp. 63-74. 
Brakus, J.J, Schmitt, B.H. and Zarantonello, L. (2009), "Brand Experience: What Is It? How Is It Measured? Does It Affect Loyalty?”, Journal of Marketing, Vol. 73 No. 3, pp. 5268.

Brodie, R.J., Hollebeek, L.D., Jurić, B. and Ilić, A. (2011), “Customer Engagement: Conceptual Domain, Fundamental Propositions, and Implications for Research", Journal of Service Research, Vol. 14 No. 3, pp. 252-271.

Bruner II, G.C. (1990), "Music, Mood, and Marketing”, Journal of Marketing, Vol. 54 No. 4, 94-104.

Calder, B.J., Malthouse, E.C. and Schaedel, U. (2009), "An Experimental Study of the Relationship between Online Engagement and Advertising Effectiveness", Journal of Interactive Marketing, Vol. 23 No. 4, pp. 321-331.

Carù, A. and Cova, B. (2006), "How to facilitate immersion in a consumption experience: Appropriation operations and service elements", Journal of Consumer Behaviour, Vol. 5 No. 1, pp. 4-14.

Celsi, R.L. and Olson, J.C. (1988), "The role of involvement in attention and comprehension processes”, Journal of Consumer Research, Vol. 15 No. 2, pp. 210-224.

Clarke, K. and Belk, R.W. (1978), “The Effects of Product Involvement and Task Definition On Anticipated Consumer Effort", in Hunt H.K. (Ed.), Advances in Consumer Research, Association for Consumer Research, Ann Arbor, MI, Vol. 6, pp. 313-318.

Dessart, L., Veloutsou, C. and Morgan-Thomas A. (2015), "Consumer engagement in online brand communities: a social media perspective", Journal of Product \& Brand Management, Vol. 24 No. 1, pp. 28-42.

Dessart, L., Veloutsou, C. and Morgan-Thomas A. (2016), "Capturing Consumer Engagement: Duality, Dimensionality and Measurement”, Journal of Marketing Management, Vol. 32 No. 5-6, pp. 399-426.

De Vries, N.J. and Carlson, J. (2014), "Examining the drivers and brand performance implications of customer engagement with brands in the social media environment", Journal of Brand Management, Vol. 21 No. 6, pp. 495-515.

Diamantopoulos, A. and Winklhofer, H.M. (2001), "Index construction with formative indicators: An alternative to scale development", Journal of Marketing Research, Vol. 38 No. 2, pp. 269-277. 
Dwivedi, A. (2015), "A higher-order model of consumer brand engagement and its impact on loyalty intentions", Journal of Retailing and Consumer Services, Vol. 24 (May), pp. 100-109.

Ellen, P.S. and Bone, P.F. (1998), "Does it Matter If it Smells? Olfactory Stimuli as Advertising Executional Cues", Journal of Advertising, Vol. 27 No. 4, pp. 29-39.

Ernst, M.O. and Bülthoff, H.H. (2004), "Merging the senses into a robust percept", Trends in Cognitive Sciences, Vol. 8 No. 4, pp. 162-169.

Fenko, A., Schifferstein, H.N.J. and Hekkert, P. (2010), "Shifts in sensory dominance between various stages of user-product interactions", Applied Ergonomics, Vol. 41 No. 1, pp. 34-40.

Fornell, C.G. and Larcker, D.F. (1981), "Evaluating Structural Equation Models with Unobservable Variables and Measurement Error", Journal of Marketing Research, Vol. 18 No. 1, pp. 39-50.

France, C., Merrilees, B. and Miller, D. (2016), “An Integrated Model of Customer-Brand Engagement: Drivers and Consequences", Journal of Brand Management, Vol. 23 No. 2, pp. 119-136.

Gentile, C., Spiller, N. and Noci, G. (2007), "How to Sustain the Customer Experience: An Overview of Experience Components that Co-create Value With the Customer", European Management Journal, Vol. 25 No. 5, pp. 395-410.

Goldsmith, R.E., Flynn, L.R. and Clark, R.A. (2011), "Materialism and brand engagement as shopping motivations”, Journal of Retailing and Consumer Services, Vol. 18 No. 4, pp. $278-284$.

Goldsmith, R.E., Flynn, L.R. and Clark, R.A. (2014), "The etiology of the frugal consumer”, Journal of Retailing and Consumer Services, Vol. 21 No. 2, pp. 175-184.

Greenwald, A.G. and Leavitt, C. (1984), “Audience Involvement in Advertising: Four Levels", Journal of Consumer Research, Vol. 11 No. 1, pp. 581-592.

Gudergan, S.P., Ringle, C.M., Wende, S. and Will, A. (2008), "Confirmatory tetrad analysis in PLS path modeling”, Journal of Business Research, Vol. 61 No. 12, pp. 1238-1249.

Hair, J.F., Hult, G.T.M., Ringle, C.M. and Sarstedt, M. (2013), A Primer on Partial Least Squares Structural Equation Modeling (PLS-SEM), Sage, Thousand Oaks.

Hair, J.F., Ringle, C.M. and Sarstedt, M. (2011), “PLS-SEM: Indeed a Silver Bullet”, Journal of Marketing Theory and Practice, Vol. 19 No. 2, pp. 139-151.

Harman, H.H. (1976), Modern Factor Analysis, University of Chicago Press, Chicago. 
Hekkert, P. and Schifferstein, H.N.J. (2008), "Introducing product experience", in Schifferstein, H.N.J. and Hekkert, P. (Eds.), Product experience, Elsevier, Amsterdam, pp. $1-8$.

Henseler, J., Ringle, C.M. and Sarstedt, M. (2016), “Testing Measurement Invariance of Composites Using Partial Least Squares”, International Marketing Review, Vol. 33 No. 3, pp. 405-431.

Henseler, J., Ringle, C.M. and Sinkovics, R.R. (2009), “The Use of Partial Least Squares Path Modeling in International Marketing”, in Sinkovics, R.R. and Ghauri, P.N. (Eds.), Advances in International Marketing, Emerald Group, Bingley, UK, pp. 277-320.

Higgins, E. Tory and Abigail A. Scholer (2009), "Engaging the Consumer: The Science and Art of the Value Creation Process", Journal of Consumer Psychology, Vol. 19 No. 2, pp. 100-114.

Holbrook, M.B. and Hirschman, E.C. (1982), "The Experiential Aspects of Consumption: Consumer Fantasies, Feelings, and Fun”, Journal of Consumer Research, Vol. 9 No. 2, pp. $132-140$.

Hollebeek, L.D. (2011a), "Demystifying customer brand engagement: Exploring the loyalty nexus", Journal of Marketing Management, Vol. 27 No. 7-8, pp. 785-807.

Hollebeek, L.D. (2011b), "Exploring customer brand engagement: definition and themes", Journal of Strategic Marketing, Vol. 19 No. 7, pp. 555-573.

Hollebeek, L.D. and Chen, T. (2014), "Exploring positively- versus negatively-valenced brand engagement: a conceptual model", Journal of Product \& Brand Management, Vol. 23 No. 1, pp. 62-74.

Hollebeek, L.D., Glynn, M.S. and Brodie, R.J. (2014), “Consumer Brand Engagement in Social Media: Conceptualization, Scale Development and Validation", Journal of Interactive Marketing, Vol. 28 No. 2, pp. 149-165.

Hollebeek, L.D., Srivastava, R.K. and Chen, T. (2016), "SD logic-informed customer engagement: integrative framework, revised fundamental propositions, and application to CRM", Journal of the Academy of Marketing Science, forthcoming.

Homans, G.C. (1958), "Social Behavior as Exchange”, American Journal of Sociology, Vol. 63 No. 6, pp. 597-606.

Houston, M.J. and Rothschild, M.L. (1978), “Conceptual and Methodological Perspectives in Involvement", in Jain S. (Ed.), Research Frontiers in Marketing: Dialogues and Directions, American Marketing Association, Chicago, pp. 184- 187. 
Hultén, B. (2011), "Sensory marketing: the multi-sensory brand-experience concept", European Business Review, Vol. 23 No. 3, pp. 256-273.

Jarvis, C.B., MacKenzie, S.B. and Podsakoff, P.M. (2003), “A Critical Review of Construct Indicators and Measurement Model Misspecification in Marketing and Consumer Research”, Journal of Consumer Research, Vol. 30 No. 2, pp. 199-218.

Johnson, A.R. and Stewart, D.W. (2005), "A reappraisal of the role of emotion in consumer behavior: traditional and contemporary approaches", in Malhotra, N.K. (Ed.), Review of Marketing Research, M.E. Sharpe, Armonk, NJ, pp. 3-33.

Kellaris, J.J. and Altsech, M.B. (1992), "The Experience of Time as a Function of Musical Loudness and Gender of Listener", in Sherry, J.F. Jr and Sternthal, B. (Eds.), Advances in Consumer Research, Association for Consumer Research, Provo, UT, Vol. 19, pp. $725-729$.

Keller, K.L. (1993), “Conceptualizing, Measuring, and Managing Customer-Based Brand Equity", Journal of Marketing, Vol. 57 No. 1, pp. 1-22.

Kroeber-Riel, W. (1979), “Activation Research: Psychobiological Approaches in Consumer Research", Journal of Consumer Research, Vol. 5 No. 4, pp. 240-250.

Kumar, V. and Pansari, A. (2016), “Competitive Advantage Through Engagement”, Journal Of Marketing Research, Vol. 53 No. 4, pp. 497-514.

Leckie, C., Nyadzayo, M.W. and Johnson, L.W. (2016), “Antecedents of consumer brand engagement and brand loyalty", Journal of Marketing Management, Vol. 32 No. 5-6, pp. 558-578.

Lemon, K.N. and Verhoef, P.C. (2016), "Understanding Customer Experience Throughout the Customer Journey", Journal of Marketing, Vol. 80 No. 6, pp. 6996.

Leone, R.P., Rao, V.R., Keller, K.L., Luo, A.M., McAlister, L., and Srivastava, R. (2006), "Linking Brand Equity to Customer Equity", Journal of Service Research, Vol. 9 No. 2, pp. $125-138$.

Lindstrom, M. (2005), "Broad sensory branding", Journal of Product \& Brand Management, Vol. 14 No. 2, pp. 84-87.

Marketing Science Institute (2014), “2014-2016 Research Priorities”, available at: www.msi.org/research/2014-2016-research-priorities/ (accessed November 15, 2015).

Mathwick, C. and Rigdon, E. (2004), "Play, Flow, and the Online Search Experience", Journal of Consumer Research", Vol. 31 No. 2, pp. 324-332. 
Merrilees, B. (2016), "Interactive brand experience pathways to customer-brand engagement and value co-creation", Journal of Product \& Brand Management, Vol. 25 No. 5, pp. 402-408.

Milliman, R.E. (1982), "Using Background Music to Affect the Behavior of Supermarket Shoppers", Journal of Marketing, Vol. 46 No. 2, pp. 86-91.

Milliman, R.E. (1986), “The Influence of Background Music on the Behavior of Restaurant Patrons", Journal of Consumer Research, Vol. 13 No. 2, pp. 286-289.

Mittal, B. and Lee, M.S. (1989), "A causal model of consumer involvement", Journal of Economic Psychology, Vol. 10 No. 3, pp. 363-389.

Nyer, P.U. (1997), "A Study of the Relationships Between Cognitive Appraisals and Consumption Emotions", Journal of the Academy of Marketing Science, Vol. 25 No. 4, pp. 296-304.

Pansari, A. and Kumar, V. (2016), "Customer engagement: the construct, antecedents, and consequences", Journal of the Academy of Marketing Science, forthcoming.

Petty, R.E., Cacioppo, J.T. and Schumann, D. (1983), "Central and Peripheral Routes to Advertising Effectiveness: The Moderating Role of Involvement", Journal of Consumer Research, Vol. 10 No. 2, pp. 135-146.

Pine, B.J. II and Gilmore, J.H. (1998), "Welcome to the experience economy", Harvard Business Review, Vol. 76 No. 4, pp. 97-106.

Podsakoff, P.M., MacKenzie, S.B., Lee, J.Y. and Podsakoff, N.P. (2003), "Common Method Biases in Behavioral Research: a Critical Review of the Literature and Recommended Remedies", Journal of Applied Psychology, Vol. 88 No. 5, pp. 879-903.

Preacher, K.J. and Hayes, A.F. (2008), "Asymptotic and resampling strategies for assessing and comparing indirect effects in multiple mediator models", Behavior Research Methods, Vol. 40 No. 3, pp. 879-891.

Quester, P. and Lim, A.L. (2003), "Product involvement/brand loyalty: is there a link?", Journal of Product \& Brand Management, Vol. 12 No. 1, pp. 22-38.

Ringle, C.M., Wende, S. and Becker, J.M. (2015), "SmartPLS 3", available at: http://www.smartpls.com (accessed November 1, 2015).

Roseman, I.J. (1991), “Appraisal determinants of discrete emotions”, Cognition and Emotion, Vol. 5 No. 3, pp. 161-200.

Schifferstein, H.N.J. (2010), "From salad to bowl: The role of sensory analysis in product experience research", Food Quality and Preference, Vol. 21 No. 8, pp. 1059-1067. 
Schmitt, B. (1999), "Experiential Marketing”, Journal of Marketing Management, Vol. 15 No. 1-3, pp. 53-67.

Shih, C.F.E. (1998), "Conceptualizing consumer experiences in cyberspace", European Journal of Marketing, Vol. 32 No. 7/8, pp. 655-663.

Spangenberg, E.R., Crowley, A.E. and Henderson, P.W. (1996), "Improving the store environment: do olfactory cues affect evaluations and behaviours?", Journal of Marketing, Vol. 60 No. 2, pp. 67-80.

Sprott, D., Czellar, S. and Spangenberg, E. (2009), "The importance of a general measure of brand engagement on market behavior: Development and validation of a scale", Journal of Marketing Research, Vol. 46 No. 1, pp. 92-104.

Smith, C.A. and Ellsworth, P.C. (1985), "Patterns of Cognitive Appraisal in Emotion", Journal of Personality and Social Psychology, Vol. 48 No. 4, pp. 813-838.

van Doorn, J., Lemon, K.N., Mittal, V., Nass, S., Pick, D., Pirner, P. and Verhoef, P.C. (2010), "Customer Engagement Behavior: Theoretical Foundations and Research Directions", Journal of Service Research, Vol. 13 No. 3, pp. 253-266.

Vargo, S.L. and Lusch R.F. (2004), "Evolving to a New Dominant Logic for Marketing”, Journal of Marketing, Vol. 68 No. 1, pp. 1-17.

Vargo, S.L. and Lusch R.F. (2008), "Service-Dominant Logic: Continuing the Evolution", Journal of the Academy of Marketing Science, Vol. 36 No. 1, pp. 1-10.

Verhoef, P.C., Lemon, K.N., Parasuraman, A., Roggeveen, A., Tsiros, M. and Schlesinger, L.A. (2009), "Customer Experience Creation: Determinants, Dynamics and Management Strategies", Journal of Retailing, Vol. 85 No. 1, pp. 31-41.

Vernuccio, M., Pagani, M., Barbarossa, C. and Pastore, A. (2015), “Antecedents of brand love in online networkbased communities. A social identity perspective", Journal of Product \& Brand Management, Vol. 24 No. 7, pp. 706-719.

Vivek, S.D., Beatty, S.E. and Morgan, R.M. (2012), "Customer Engagement: Exploring Customer Relationships Beyond Purchase", Journal of Marketing Theory and Practice, Vol. 20 No. 2, pp. 127-145.

Vivek, S.D., Beatty, S.E., Dalela, V., and Morgan, R.M. (2014), "A generalized multidimensional scale for measuring customer engagement", Journal of Marketing Theory and Practice, Vol. 22 No. 4, pp. 401-420.

Yoo, B., Donthu, N. and Lee, S. (2000), "An Examination of Selected Marketing Mix Elements and Brand Equity", Journal of the Academy of Marketing Science, Vol. 28 No. 2, pp. 195-211. 
Yoo, B. and Donthu, N. (2001), "Developing and validating a multidimensional consumerbased brand equity scale", Journal of Business Research, Vol. 52 No. 1, pp. 1-14.

Zaichkowsky, J.L. (1985), "Measuring the Involvement Construct", Journal of Consumer Research, Vol. 12 No. 3, pp. 341-352.

Zaichkowsky, J.L. (1994), "Research Notes: The Personal Involvement Inventory: Reduction, Revision, and Application to Advertising”, Journal of Advertising, Vol. 23 No. 4, pp. $59-70$.

Zhao, X., Lynch, J.G. Jr., and Chen, Q. (2010), "Reconsidering Baron and Kenny: Myths and Truths about Mediation Analysis", Journal of Consumer Research, Vol. 37 No. 2, pp. 197-206. 
Table I Definitions of consumer brand engagement and its related terms

\begin{tabular}{|c|c|c|}
\hline Author(s) & Term & Definition \\
\hline $\begin{array}{l}\text { Bowden }(2009, \mathrm{p} . \\
65)\end{array}$ & Engagement & $\begin{array}{l}\text { [A] psychological process that models the underlying mechanisms } \\
\text { by which customer loyalty forms for new customers of a service } \\
\text { brand as well as the mechanisms by which loyalty may be } \\
\text { maintained for repeat purchase customers of a service brand. }\end{array}$ \\
\hline $\begin{array}{l}\text { Calder et al. }(2009 \text {, } \\
\text { p. } 322)\end{array}$ & $\begin{array}{l}\text { Consumer } \\
\text { engagement with } \\
\text { website }\end{array}$ & [A] collection of experiences with the site. \\
\hline $\begin{array}{l}\text { Higgins and Scholer } \\
(2009, \text { p. 102) }\end{array}$ & Engagement & $\begin{array}{l}\text { Engagement is a state of being involved, occupied, fully absorbed, } \\
\text { or engrossed in something - sustained attention. }\end{array}$ \\
\hline $\begin{array}{l}\text { Sprott et al. }(2009 \text {, } \\
\text { p. } 95)\end{array}$ & $\begin{array}{l}\text { Brand engagement } \\
\text { in self-concept }\end{array}$ & $\begin{array}{l}\text { [A]n individual difference representing consumers' propensity to } \\
\text { include important brands as part of how they view themselves. }\end{array}$ \\
\hline $\begin{array}{l}\text { van Doorn et al. } \\
\text { (2010, p. 253) }\end{array}$ & $\begin{array}{l}\text { Customer } \\
\text { engagement } \\
\text { behavior }\end{array}$ & $\begin{array}{l}{[\mathrm{T}] \text { he customers' behavioral manifestation toward a brand or firm, }} \\
\text { beyond purchase, resulting from motivational drivers. }\end{array}$ \\
\hline $\begin{array}{l}\text { Brodie } \text { et al. (2011, } \\
\text { p. 260) }\end{array}$ & $\begin{array}{l}\text { Customer } \\
\text { engagement }\end{array}$ & $\begin{array}{l}\text { [A] psychological state that occurs by virtue of interactive, } \\
\text { cocreative customer experiences with a focal agent/object (e.g., a } \\
\text { brand) in focal service relationships. It occurs under a specific set } \\
\text { of context-dependent conditions generating differing CE } \\
\text { [Customer Engagement] levels; and exists as a dynamic, iterative } \\
\text { process within service relationships that cocreate value. CE plays } \\
\text { a central role in a nomological network governing service } \\
\text { relationships in which other relational concepts (e.g., } \\
\text { involvement, loyalty) are antecedents and/or consequences in } \\
\text { iterative CE processes. It is a multidimensional concept subject to } \\
\text { a context- and/or stakeholder-specific expression of relevant } \\
\text { cognitive, emotional and/or behavioral dimensions. }\end{array}$ \\
\hline $\begin{array}{l}\text { Hollebeek et al. } \\
\text { (2014, p. 154) }\end{array}$ & $\begin{array}{l}\text { Consumer brand } \\
\text { engagement }\end{array}$ & $\begin{array}{l}\text { [A] consumer's positively valenced brand-related cognitive, } \\
\text { emotional and behavioral activity during or related to focal } \\
\text { consumer/brand interactions. }\end{array}$ \\
\hline $\begin{array}{l}\text { Vivek et al. }(2014, \\
\text { p. } 401)\end{array}$ & $\begin{array}{l}\text { Customer } \\
\text { engagement }\end{array}$ & $\begin{array}{l}\text { CE [Customer Engagement] goes beyond purchase and is the } \\
\text { level of the customer's (or potential customer's) interactions and } \\
\text { connections with the brand or firm's offerings or activities, often } \\
\text { involving others in the social network created around the } \\
\text { brand/offering/activity. }\end{array}$ \\
\hline $\begin{array}{l}\text { Dwivedi }(2015, \mathrm{p} \\
\text { 100) }\end{array}$ & $\begin{array}{l}\text { Consumer brand } \\
\text { engagement }\end{array}$ & $\begin{array}{l}{[C] \text { onsumers' positive, fulfilling, brand-use-related state of mind }} \\
\text { that is characterized by vigor, dedication and absorption. }\end{array}$ \\
\hline $\begin{array}{l}\text { Dessart et al. }(2016, \\
\text { p. 409) }\end{array}$ & $\begin{array}{l}\text { Consumer } \\
\text { engagement }\end{array}$ & $\begin{array}{l}{[T] \text { he state that reflects consumers' individual dispositions toward }} \\
\text { engagement foci, which are context-specific. Engagement is } \\
\text { expressed through varying levels of affective, cognitive, and } \\
\text { behavioural manifestations that go beyond exchange situations. }\end{array}$ \\
\hline
\end{tabular}


Table II Discriminant validity

\begin{tabular}{llllllll}
\hline & INV & SBE & COG & AFF & ACT & CBE & BE \\
INV & .760 & & & & & & \\
SBE & .522 & .867 & & & & & \\
COG & .457 & .512 & .881 & & & & \\
AFF & .553 & .564 & .674 & .862 & & & \\
ACT & .301 & .333 & .365 & .531 & .935 & & \\
CBE & .529 & .558 & .706 & .922 & .800 & n/a & \\
BE & .476 & .567 & .467 & .609 & .528 & .667 & .924 \\
Mean & 5.740 & 5.417 & 4.667 & 5.626 & 5.722 & 5.551 & 5.381 \\
SD & .824 & 1.005 & 1.301 & 1.050 & 1.346 & 1.013 & 1.324 \\
Notes: INV: personal involvement; SBE: sensory brand experience; COG: cognitive \\
processing; AFF: affection; ACT: activation; CBE; formatively measured consumer brand \\
engagement; BE: brand equity; n/a: not applicable; SD: standard deviation. The square root of \\
AVE is presented on the diagonal.
\end{tabular}

Table III Structural model estimates

\begin{tabular}{|c|c|c|c|c|}
\hline & Path coefficient & $t$-value & Construct & $R^{2}$ \\
\hline H1a: INV $\ddagger$ COG & $.261 * * *$ & 7.623 & Cognitive processing & .312 \\
\hline H1b: INV $\ddagger$ AFF & $.355 * * *$ & 9.793 & Affection & .410 \\
\hline H1c: INV $\ddagger$ ACT & $.175 * * *$ & 5.015 & Activation & .133 \\
\hline $\mathrm{H} 2: \mathrm{INV} \ddagger \mathrm{BE}$ & $.091 * * *$ & 3.611 & Brand equity & .505 \\
\hline H3a: SBE $\neq$ COG & $.376^{* * *}$ & 12.551 & & \\
\hline H3b: SBE $\ddagger$ AFF & $.379^{* * *}$ & 11.129 & & \\
\hline H3c: SBE $\ddagger$ ACT & $.242 * * *$ & 6.838 & & \\
\hline $\mathrm{H} 4: \mathrm{SBE} \ddagger \mathrm{BE}$ & $.252 * * *$ & 7.673 & & \\
\hline $\mathrm{H} 5: \mathrm{CBE} \ddagger \mathrm{BE}$ & $.478 * * *$ & 13.051 & & \\
\hline \multicolumn{5}{|c|}{ Note: $* * * p<0.01$ (two-tailed test). } \\
\hline
\end{tabular}




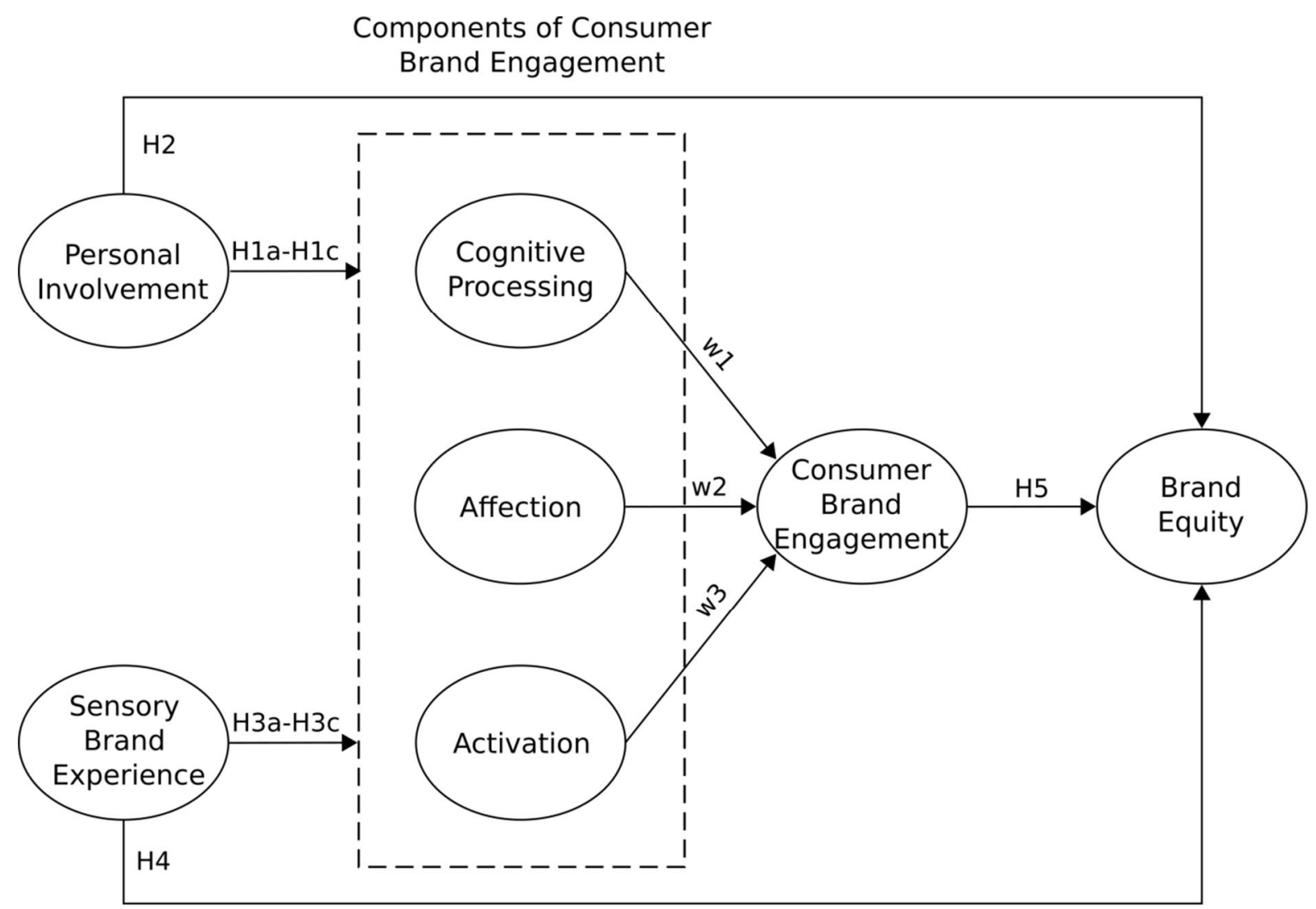

Figure 1 Research model 


\section{Appendix Survey items}

Personal involvement $(\mathrm{CR}=0.931, \mathrm{AVE}=0.577)$

I think [brand] brand is...

1. unimportant-important

2. boring-interesting

3. irrelevant-relevant

4. unexciting—exciting

5. meaningless-meaningful

6. repulsive-appealing

7. mundane-exceptional

8. worthless-valuable

9. uninvolving_involving

10. not needed-needed

Sensory brand experience $(\mathrm{CR}=0.858, \mathrm{AVE}=0.752)$

1. [Brand] brand makes an impression on my visual sense and other senses.

2. [Brand] brand is interesting in a sensory way.

3. [Brand] brand does not appeal to my senses.*

Consumer brand engagement ${ }^{1}$

Cognitive processing $(\mathrm{CR}=0.912, \mathrm{AVE}=0.777)$

1. Using [brand's] products gets me to think about [brand name] brand.

2. I think about [brand] brand a lot when I'm using their products.

3. Using [brand] products stimulates my interest to learn more about [brand] brand.

Affection $(\mathrm{CR}=0.920, \mathrm{AVE}=0.743)$

1. I feel very positive when I use [brand's] products.

2. Using [brand's] products makes me happy.

3. I feel good when I use [brand's] products.

4. I'm proud to use [brand's] products.

Activation $(\mathrm{CR}=0.954, \mathrm{AVE}=0.874)$

1. I use [brand's] tableware more than the tableware of other brands.

2. Whenever I'm using tableware, I usually use [brand].

3. When I use tableware, I use [brand's] products.

Brand equity $(\mathrm{CR}=0.959, \mathrm{AVE}=0.853)$

1. It makes sense to use [brand's] products instead of any other similar products.

2. Even if other tableware had the same features as [brand], I would still use [brand].

3. If there were other tableware as good as [brand], I would still use [brand].

4. If other tableware did not differ from [brand] in any way, I would still use [brand]. 
Notes: CR: composite reliability; AVE: average variance extracted; *: dropped; ${ }^{1}:$ a higher-order construct that consists of cognitive processing, affection, and activation. All items were measured using a 7-point Likert scale except personal involvement, which was measured using a 7-point semantic differential scale. 